\title{
Stewartia 'Scarlet Sentinel'
}

\author{
Peter Del Tredici ${ }^{1}$ and Jianhua $\mathbf{L i}^{2}$ \\ Arnold Arboretum of Harvard University, 125 Arborway, Jamaica Plain, \\ MA 02130
}

Additional index words. Stewartia pseudocamellia, Stewartia ovata, hybrid tree, Arnold Arboretum, RAPD analysis, nuclear ribosomal DNA

The genus Stewartia (Theaceae) holds considerable interest for botanists because of its disjunct distribution in eastern Asia and eastern North America (Spongberg, 1974). The genus is also of interest to horticulturists because of the ornamental merit of several of its species which produce showy summer flowers, brightly colored fall foliage and strikingly patterned, exfoliating bark (Dirr and Heuser, 1987).

\section{Origin}

Stewartia 'Scarlet Sentinel' is a unique tree that originated as a spontaneous, openpollinated seedling at the Arnold Arboretum of Harvard Univ. in Jamaica Plain, Mass. [U.S. Dept. of Agriculture (USDA) hardiness zone $6 \mathrm{a}]$. The plant is a putative spontaneous hybrid between $S$. pseudocamellia Maximowicz (AA accession \#11440-A) and S. ovata (Cavanilles) Weatherby f. grandiflora (Bean) Kobuski (AA\#18244-C), which are growing adjacent to one another in the "Chinese Path" section of the Arnold Arboretum (Fig. 1). The former plant was raised from seed collected from the wild in Korea by E.H. Wilson in 1918, while the latter was collected by T.G. Harbison in 1925 from the wild in Highlands, N.C. While both species are considered highly ornamental, only $S$. pseudocamellia has become well established in the nursery trade. The complex taxonomy of both species is covered in treatments by Wood (1959) and Spongberg (1974).

The plant now known as 'Scarlet Sentinel' was originally collected in 1982 as one of a group of spontaneous seedlings growing beneath S. pseudocamellia, AA \#11440-A. The seedlings, which were assumed to be $S$. pseudocamellia, were collected for distribution at the Arboretum plant sale under AA \#538-82. One of the seedlings was cultivated on the private property of the senior author, in the town of Harvard, Mass. (USDA hardiness zone $6 \mathrm{~b}$ ). It was not until the plant flowered for the first time in 1992 , at $\approx 12$ years of age, that its hybrid nature became apparent.

Received for publication 20 Feb. 2001. Accepted for publication 25 July 2001. We thank Tom Ward, Jack Alexander, and Bob Famiglietti of the Arnold Arboretum for help with propagation work and Stephen Spongberg and two anonymous reviewers for their helpful comments on the manuscript. ${ }^{1}$ Director of Living Collections.

${ }^{2}$ Taxonomist.

\section{Description}

'Scarlet Sentinel' has a narrow, upright growth habit, reaching $6.5 \mathrm{~m}$ in height and $2.5 \mathrm{~m}$ in width after 12 years of growth from seed. At 20 years of age, the tree is $\approx 9 \mathrm{~m}$ tall and $5 \mathrm{~m}$ wide, having recovered from losing its leader during a heavy snowstorm in Dec. 1996. 'Scarlet Sentinel' produces distinctive bark that exfoliates in thin strips, 2 to $5 \mathrm{~mm}$ wide (Fig. 2) and leaves that are alternate, simple and ovate to broad elliptic. Both the upper and lower leaf surfaces are glabrous to slightly pubescent and smooth to the touch; the petiole is $\approx 1 \mathrm{~cm}$ long with slight wings that enclose the distally developing bud; the leaf blade is 8 to $12 \mathrm{~cm}$ long $\times 4$ to $7 \mathrm{~cm}$ wide, with an acuminate apex and a rounded to cuneate base; and the leaf margins are finely serrulate with apiculate teeth.

'Scarlet Sentinel' produces relatively large flowers that are between 8 and $10 \mathrm{~cm}$ wide when fully open. The most conspicuous feature of these flowers is their scarlet-colored anther filaments [Royal Horticultural Society (RHS) color chart \#58B in the red-purple group] (Royal Horticultural Society, 1987) (Fig. 1). The ovary of the flower is $\approx 6 \mathrm{~mm}$ long, and is covered with dense hairs (pilose); its five styles are fused for the basal $1 / 3$ of their length, while their upper $2 / 3$ are free. The base of the ovary and the free portion of the styles are light yellow, while the apex of the ovary and the fused portion of the styles are the same red color as the anther filaments. The flowers typically have five petals, but many also have one or two small petaloid structures at the base of one of the petals, that are $\approx 18 \mathrm{~mm}$ long $\times 4 \mathrm{~mm}$ wide. The flowers appear to be sterile, producing little, if any, viable pollen and no mature fruits. Table 1 summarizes the morphological intermediacy of 'Scarlet Sentinel' relative to $S$. pseudocamellia and $S$. ovata f. grandiflora.

\section{Molecular evidence of hybridity}

The morphological intermediacy of 'Scarlet Sentinel' between $S$. ovata f. grandiflora and $S$. pseudocamellia strongly suggests that the cultivar is a hybrid between the two species. In order to verify this supposition, we conducted molecular analyses of both species and their putative hybrid. Total genomic DNA was extracted using a modified CTAB procedure (Doyle and Doyle, 1987) from young leaves representing 'Scarlet Sentinel' and three accessions of each of the two parents at the Arnold Arboretum (S. ovata f. grandiflora: AA \#18244A, B, C; and S. pseudocamellia: AA \#1269-83A, 11440-B, and 183-79A). Geneclean kit was used to purify extractions (Bio101, Vista, Calif.).

$R A P D$ analysis. This molecular method has been successfully used to provide evidence for hybrids in Nuphar (Nymphaeaceae) (Padgett et al., 1998). Analysis of random amplified polymorphisms of DNA (RAPD) was carried out using Perkin-Elmer 9600 thermocycler (Applera, Foster City, Calif.) in $10.0 \mu \mathrm{L}$ reactions containing $1.0 \mu \mathrm{L}$ of $10 \times$ Taq polymerase buffer, $0.3 \mu \mathrm{L}$ of magnesium $(25 \mu \mathrm{M}), 0.8 \mu \mathrm{L}$ of DNTPs (each $2.5 \mu \mathrm{M}), 1.0$ $\mu \mathrm{L}$ of 10 -mer oligo, $0.2 \mu \mathrm{L}$ of Taq polymerase (one unit), 50-100 ng of DNA template, and sterilized distilled water. Twenty random 10mer oligo primers (OPA 1-20; Operon Tech., Alameda, Calif.) were used to amplify DNAs (Table 2). The thermocycler program consisted of a $2.5 \mathrm{~min}$. hotstart and 44 cycles, the first of which was composed of $30 \mathrm{~s}$ at $94^{\circ} \mathrm{C}$, $1 \mathrm{~min}$ at $35^{\circ} \mathrm{C}$, and $2 \mathrm{~min}$ at $72^{\circ} \mathrm{C}$, and each of the other 43 cycles consisted of $1 \mathrm{~min}$ at $94^{\circ} \mathrm{C}$, $1 \mathrm{~min}$ at $35^{\circ} \mathrm{C}$, and $2 \mathrm{~min}$ at $72^{\circ} \mathrm{C}$. Polymerase chain reaction (PCR) products were separated

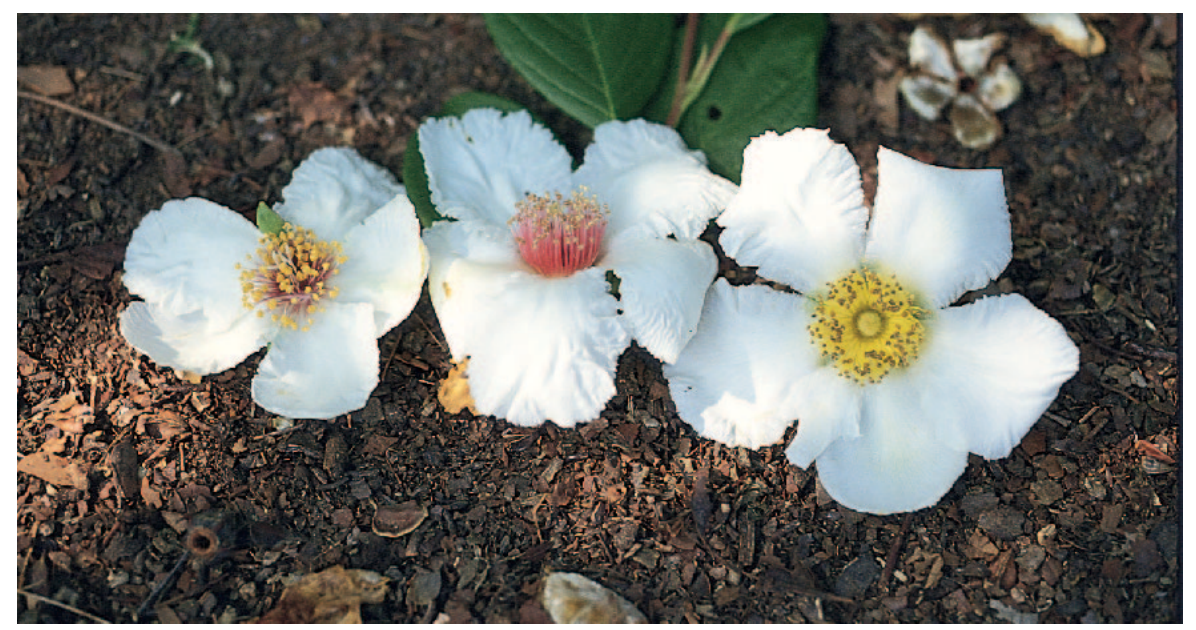

Fig. 1. 'Scarlet Sentinel' (center) with its putative parents, S. pseudocamellia (right) and S. ovata f. grandiflora (left). 


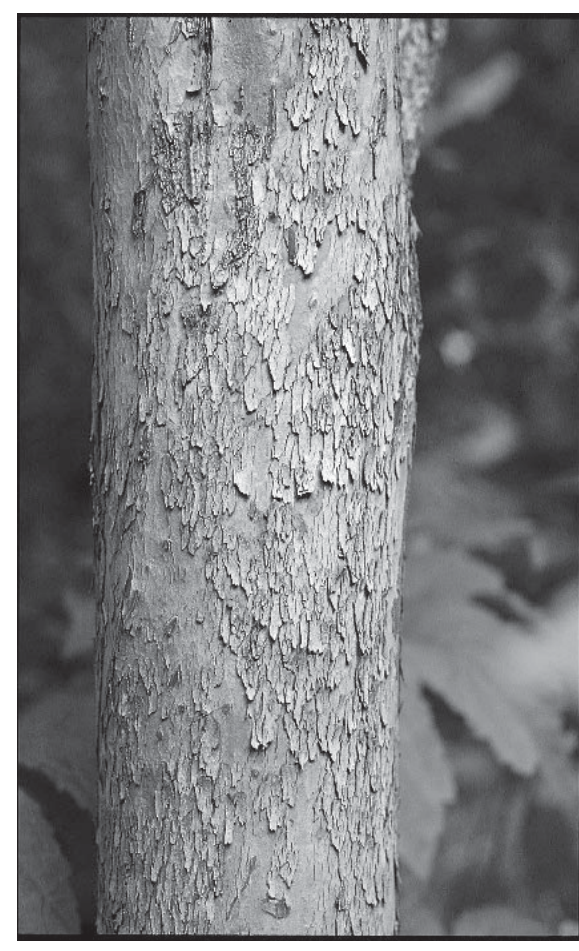

Fig. 2. A close-up of the exfoliating bark of 'Scarlet Sentinel'.

electrophoretically on $1 \%$ agarose gel in $1 \times$ TBE (tris-borate-EDTA) buffer and visualized with ethidium bromide under an ultraviolet transilluminator. Five of the 20 primers produced one or more markers that were unique to either parent and also shared by the hybrid (Fig. 3). Other markers were nonspecific. Five markers were unique to $S$. ovataf. grandiflora and eight markers were specific to $S$. pseudocamellia, and all of these markers also occurred in 'Scarlet Sentinel' (Table 2), strongly suggesting that the plant is a hybrid between the two species.

Sequence analysis of nuclear ribosomal DNA. Nuclear ribosomal DNA (nrDNA) is biparentally inherited; thus it is expected that the hybrid would show additivity of nucleotides that are unique to each parent (Kim and Jansen, 1998). In this study, we conducted PCR to amplify the internal transcribed spacer (ITS) region of nrDNA using primers, ITS4 and ITSLEU (Baum et al., 1998). PCR products were cloned using the pGEM $^{\circledR}$-T easy vector system (Promega, Madison, Wisc.) and Epicurian Coli ${ }^{\circledR} \mathrm{XL1-Blue}$ competent cells (Stratagene, Lajolla, Calif.) and following manufacturers' instructions. Two to three clones containing DNA inserts were selected and their ITS inserts were sequenced. Sequencing procedures and sequence editing have been described in detail by $\mathrm{Li}$ and Donogue (1999). Plant material used in this analysis was collected from: 'Scarlet Sentinel', S. ovata f. grandiflora (AA\#18244-C), S. pseudocamellia (AA \#11440-A), and five seedlings raised from seeds produced by an artificial hybridization of AA \# 18244-C and AA \# 11440-A, carried out in June 1998 and accessioned as AA \# 295-98 A-E. The ITS sequences have been submitted to the GeneBank and their

Table 1. Morphology of 'Scarlet Sentinel' in comparison to its putative parents, S. ovata f. grandiflora and S. pseudocamellia. Measurements represent the range of variation observed for 10 flowers per taxon.

\begin{tabular}{|c|c|c|c|}
\hline $\begin{array}{l}\text { Morphological } \\
\text { feature }\end{array}$ & $\begin{array}{l}\text { Stewartia ovata } \\
\text { f. grandiflora } \\
\text { (AA \# 18244-C) }\end{array}$ & $\begin{array}{c}\text { Stewartia } \\
\text { pseudocamellia } \\
\text { (AA \# 11440-A) }\end{array}$ & $\begin{array}{l}\text { Scarlet } \\
\text { Sentinel }\end{array}$ \\
\hline $\begin{array}{l}\text { Number of } \\
\text { floral bracts }\end{array}$ & 1 & 2 & 2 \\
\hline $\begin{array}{l}\text { Floral bract lengths } \\
(\mathrm{mm})(\text { average })\end{array}$ & $10-13(11.0)$ & $2-4 ; 7-8(2.8 ; 7.6)$ & $4-10 ; 7-12(6.0 ; 8.8)$ \\
\hline Petiole type & winged & nonwinged & semiwinged \\
\hline $\begin{array}{l}\text { Fully open flower } \\
\text { diameter }(\mathrm{cm})\end{array}$ & $7-9$ & $7.5-9.5$ & $8-10$ \\
\hline Sepal length (mm) & $15-22$ & $10-14$ & $12-14$ \\
\hline Ovary length (mm) & 5 & $6-9$ & 6 \\
\hline Style length (mm) & $12-13$ & $8-12$ & $9-12$ \\
\hline Styles free or fused & $100 \%$ free & $100 \%$ fused & $\begin{array}{l}\text { fused for the basal } \\
30 \% \text { of their length }\end{array}$ \\
\hline $\begin{array}{l}\text { Anther filament } \\
\text { color (RHS chart) }\end{array}$ & $\begin{array}{c}83 \mathrm{C} \\
\text { (violet group) }\end{array}$ & $\begin{array}{c}16 \mathrm{~B} \\
\text { (yellow-orange group) }\end{array}$ & $\begin{array}{c}58 \mathrm{~B} \\
\text { (red-purple group) }\end{array}$ \\
\hline Bloom times & & & \\
\hline $\begin{array}{l}\text { (USDA zone 6) } \\
\text { Fall color of leaves }\end{array}$ & $\begin{array}{l}\text { most of July } \\
\text { vellow }\end{array}$ & $\begin{array}{l}\text { mid-June to mid-July } \\
\text { red to burgundy }\end{array}$ & $\begin{array}{l}\text { late June to late July } \\
\text { orange to red }\end{array}$ \\
\hline Bark type & nonexfoliating & $\begin{array}{l}\text { exfoliating in large, } \\
\text { irregular plates }\end{array}$ & $\begin{array}{l}\text { exfoliating in thin, } \\
\text { linear strips }\end{array}$ \\
\hline
\end{tabular}

Table 2. Summary of RAPD and nrDNA ITS sequence analyses of 'Scarlet Sentinel' and its putative parents S. ovata f. grandiflora and S. pseudocamellia.

\begin{tabular}{|c|c|c|c|}
\hline $\begin{array}{l}\text { Oligo primer number } \\
\text { (sequence) or } \\
\text { nucleotide site number }\end{array}$ & $\begin{array}{l}\text { Total number of } \\
\text { additive RAPD } \\
\text { markers or } \\
\text { nucleotides in } \\
\text { Scarlet Sentinel }\end{array}$ & $\begin{array}{l}\text { RAPD markers } \\
\text { nucleotides unique } \\
\text { to Stewartia ovata } \\
\text { f. grandiflora } \\
\text { shared with } \\
\text { Scarlet Sentinel }\end{array}$ & $\begin{array}{c}\text { RAPD markers } \\
\text { nucleotides unique } \\
\text { to Stewartia } \\
\text { pseudocamellia } \\
\text { shared with } \\
\text { Scarlet Sentinel }\end{array}$ \\
\hline 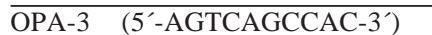 & 3 & 1 & 2 \\
\hline OPA-4 (5'-AATCAGGGCTG-3') & 2 & 1 & 1 \\
\hline OPA-15 (5'-TTCCGAACCC- $\left.3^{\prime}\right)$ & 3 & 1 & 2 \\
\hline OPA-18 (5'-AGGTGACCGT- $\left.3^{\prime}\right)$ & 2 & 1 & 1 \\
\hline OPA-20 (5'-GTTGCGATCC-3') & 3 & 1 & 2 \\
\hline 56 & $\mathrm{C}+\mathrm{T}$ & $\mathrm{C}$ & $\mathrm{T}$ \\
\hline 79 & $\mathrm{~A}+\mathrm{G}$ & A & G \\
\hline 90 & $\mathrm{~A}+\mathrm{T}$ & A & $\mathrm{T}$ \\
\hline 187 & $\mathrm{~T}+\mathrm{C}$ & $\mathrm{T}$ & $\mathrm{C}$ \\
\hline 204 & $\mathrm{C}+\mathrm{A}$ & $\mathrm{C}$ & A \\
\hline 212 & $\mathrm{G}+\mathrm{A}$ & G & A \\
\hline 216 & $\mathrm{~T}+\mathrm{A}$ & $\mathrm{T}$ & A \\
\hline 543 & $\mathrm{~T}+\mathrm{C}$ & $\mathrm{T}$ & $\mathrm{C}$ \\
\hline 573 & $A+T$ & A & $\mathrm{T}$ \\
\hline
\end{tabular}

accession numbers are AF339861 to AF339880. The lengths of the ITS region varied from 664 to 671 base pairs and visual alignment generated a data set of 686 bases, 79 of which were variable. 'Scarlet Sentinel' showed additivity at nine sites that have unique nucleotides in all clones of each parent as did the artificial hybrid seedlings (AA \# 295-98) (Table 2). For example, in site 56 of the ITS region, cytosine $(\mathrm{C})$ is unique to all three clones of $S$. ovata f. grandiflora, and thymine (T) to S. pseudocamellia, while in hybrids both $\mathrm{C}$ and $\mathrm{T}$ are observed in their clones. Therefore, both RAPD and DNA sequence analyses provide additional evidence that 'Scarlet Sentinel' is a hybrid between $S$. ovata f. grandiflora and S. pseudocamellia.

\section{Propagation and availability}

'Scarlet Sentinel' has been successfully propagated by rooting softwood cuttings, by winter grafting of dormant scions onto seedlings of $S$. pseudocamellia, and by summer budding onto seedlings of $S$. ovata. One com- mercial nursery in Connecticut is currently producing plants of 'Scarlet Sentinel' from softwood cuttings. In contrast, propagation efforts at the Arnold Arboretum have met with limited success. Softwood cuttings placed under intermittent mist produced roots in high percentages $(60 \%$ to $100 \%)$ when collected between mid-June and early August and treated with K-IBA (aqueous solutions in concentrations of 2,500 to $10,000 \mathrm{ppm}$ ). While most of the cuttings initiated growth the following spring, many of them died during the course of the following summer after producing 5 to 10 $\mathrm{cm}$ of new growth. Modifications in the rooting medium, the type of container, the mode of overwintering, and the timing of transplanting have increased survival of some cuttings, but most of these died during their second summer of growth. Survival problems following the rooting of Stewartia cuttings are well documented in the literature (Dirr and Heuser, 1987; Curtis et al., 1996; Struve and Lagrimini, 1999), and have undoubtedly played a role in the Arboretum's limited success in propagating 'Scarlet Sentinel'. 


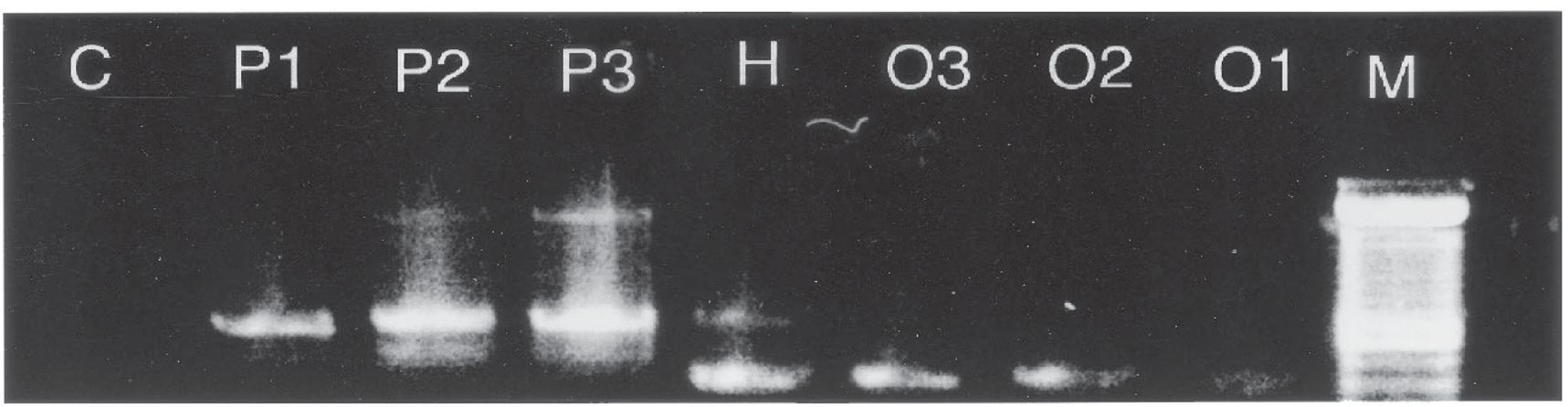

Fig. 3. RAPD banding pattern of OPA-4 primer for Stewatia species. $\mathrm{C}=$ control; $\mathrm{O}=$ S. ovata $\mathrm{f}$. grandflora $; \mathrm{P}=$ S. pseudocamellia $; \mathrm{H}=$ putative hybrid between $\mathrm{P}$ and $\mathrm{O} . \mathrm{M}=\mathrm{DNA}$ size marker.

Growers interested in obtaining scion material under a licensing agreement should write to: Stewartia Distribution, Arnold Arboretum, 125 Arborway, Jamaica Plain, MA 02130.

\section{Literature Cited}

Baum, D.A., R.L. Small, and J.F. Wendel, 1998. Biogeography and floral evolution of Baobabs (Adansonia, Bombacaceae) as inferred from multiple data sets. Syst. Biol. 47:181-207.

Curtis, D.L., T.G. Ranney, F.A. Blazich, and E.P. Whitman. 1996. Rooting and subsequent overwinter survival of stem cuttings of Stewartia ovata. J. Environ. Hort. 14:163-166.
Dirr, M.A. and C.W. Heuser, Jr. 1987. The reference manual of woody plant propagation. Varsity Press, Athens, Ga.

Doyle, J.J. and J.L. Doyle. 1987. A rapid DNA isolation procedure for small quantities of fresh leaf tissue. Phytochem. Bul. 19:1-15.

Kim, K.-J. and R. Jansen, 1998. A chloroplast DNA phylogeny of lilacs (Syringa, Oleaceae): Plastome groups show a strong correlation with crossing groups. Amer. J. Bot. 85:1338-1351.

Li, J. and M.J. Donoghue 1999. Phylogenetic relationships in the Hamamelidoideae inferred from sequences of trn non-coding regions of chloroplast DNA. Harvard Pap. Bot. 4:343-356.

Padgett, D.J., D.H. Les, and G.E. Crow, 1998.
Evidence for the hybrid origin of Nuphar xrubrodisca (Nymphaeaceae). Amer. J. Bot. 85:1468-1476.

Royal Horticultural Society, London. 1987. Color chart. Leiden, Flower council of Holland.

Spongberg, S.A. 1974. A review of deciduousleaved species of Stewartia (Theaceae). J. Arnold Arbor. 55:182-214

Struve, D.K. and L.M. Lagrimini, 1999. Survival and growth of Stewartia pseudocamellia rooted cuttings and seedlings. J. Environ. Hort. 17:5356.

Wood, C.E., Jr. 1959. The genera of Theaceae of the southeastern United States. J. Arnold Arbor. 40:413-419. 